\title{
GRAIN SPOTTING OF RICE CAUSED BY PESTALOTIOPSIS GUEPINII (DESM.) STAY - A NEW RECORD
}

\author{
Pranami ChOWdhury ${ }^{1}$, Shamim Shams** AND M.A. Bashar \\ Department of Botany, University of Dhaka, Dhaka-1000, Bangladesh
}

Key words: Grain spotting, Rice, Pestalotiopsis guepinii, New record

Pestalotiopsis guepinii (Desm.) Stay. a Celomycetous fungus was isolated from spotted grains of two rice varieties i.e., BRRI 29 and Pajam during Boro and Aman seasons from 2012 to 2013. Both the rice varieties were inoculated with P. guepinii following seed inoculation technique and found to be pathogenic to the plant. Association of P. guepinii with rice grains is a new record.

Rice is one of the major cereal crops and the cheapest source of food energy for $50 \%$ of the total world population predominantly in the developing countries. It is cultivated in Bangladesh in different seasons, namely Aus, Aman and Boro. Rice is affected by more than 60 diseases in all rice growing areas of the world among these 31 are reported from Bangladesh ${ }^{(1)}$. It suffers from 17 different seed borne diseases of which 11 seed transmitted fungal pathogens are responsible for causing disease in the field ${ }^{(2)}$. Shamsi et al. reported association of 15 species of fungi with infected rice grains ${ }^{(3)}$. Mew and Gonzales reported 104 species of fungi on rice grains ${ }^{(4)}$. More than $50 \%$ of the seeds were spotted or discolored which ultimately reduced the market prize of rice ${ }^{(5)}$.

Pathogens associated with seeds cause germination failure, post emergence seedling infection and also seedling blight. A very little information is available on the impact of farmers seed processing or management practices on the seed associated with fungi. So the present work was undertaken to search the fungi associated with rice grains with changed climate.

The present study was based on spotted rice grains of two rice varieties, namely BRRI 29 and Pajam collected from farmers of Raiganj and Sirajganj (Rajshahi division), Gopalpur and Joydebpur (Dhaka division), Comilla and Laksmipur (Chittagong division), Rupatali and Rahmatpur (Barisal division) during Boro and Aman seasons of 2012 and 2013. Samples were collected after harvesting and placed in clean brown paper bag labeled properly and preserved at $4^{\circ} \mathrm{C}$ in refrigerator for subsequent uses.

The fungi were isolated from the samples following the "Tissue planting method" on PDA medium and "Blotter" method(6). After surface sterilization with 10\% Chlorox for 10 min 400 seeds of each samples were placed on three layers of moist blotting paper

*Author for correspondence: <Prof.shamsi@gmail.com>. ${ }^{1}$ Directorate of Secondary and Higher Education, Dhaka, Bangladesh. A part of Ph. D. thesis of first author. 
(Whatman No. 1) in Petri plates at 10 seeds per plate. Petri plates with inoculated rice grains were incubated for $5-7$ days at $25 \pm 2^{\circ} \mathrm{C}$. Fungi grew from the seeds were transferred to separate PDA plates and PDA slants for further studies and preservation. The isolated fungi were identified based on morphological characteristics observed under a compound microscope following standard literature ${ }^{(7-12)}$. Prevalence $(\%)$ of fungi in different specimens was also recorded.
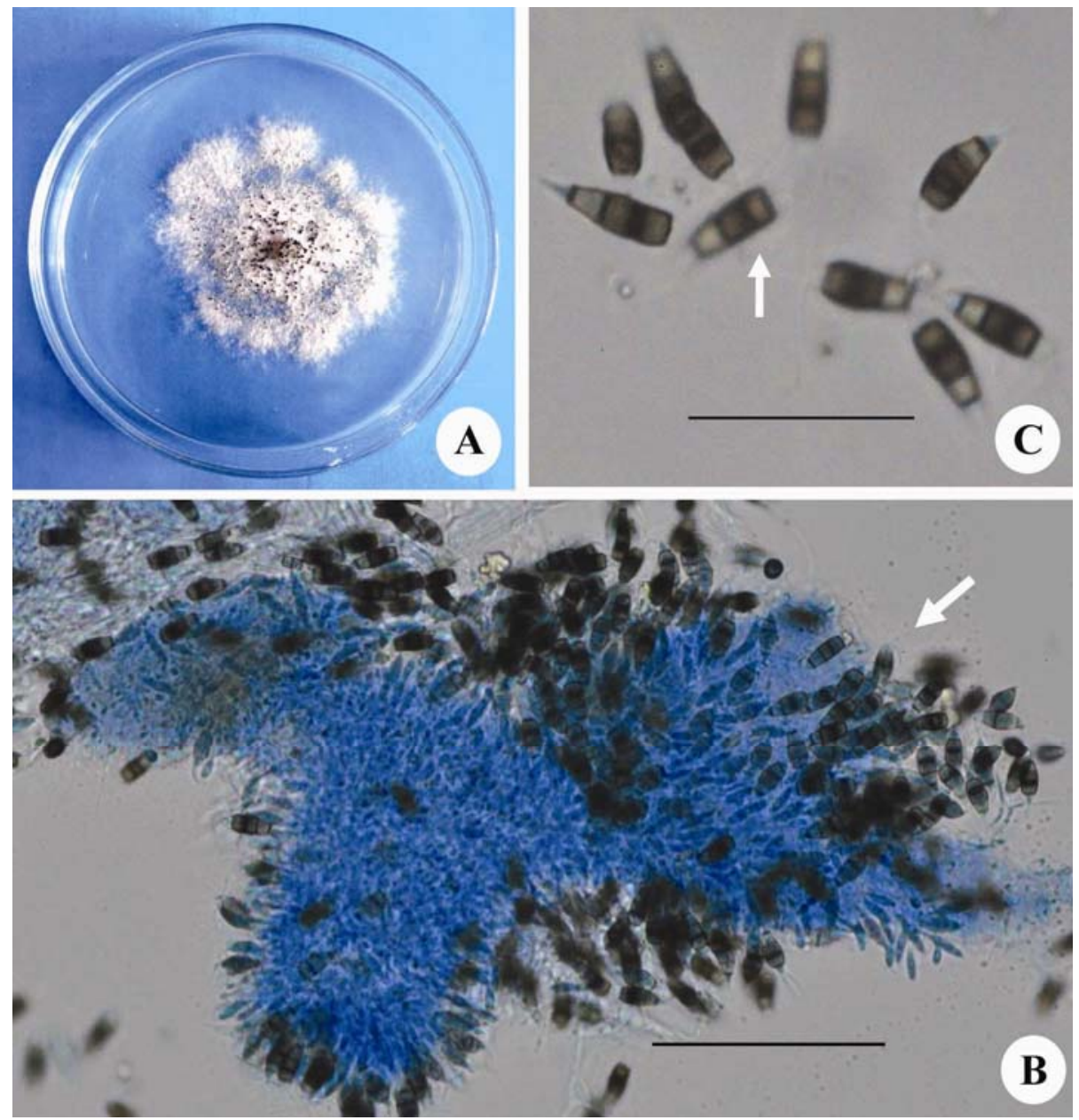

Fig. 1. Colony (A), Acervulus (B) and Conidia (C) of Pestalotiopsis guepinii:.

(B. Bar $=50 \mu \mathrm{m}$, C. Bar $=25 \mu \mathrm{m}$ ).

Pathogenicity of the test fungus was done following seed inoculation technique ${ }^{(13)}$. Four hundred healthy and 400 spotted grains were selected from BRRI 29 and Pajam and soaked in distilled water in a beaker for three hours then surface sterilized with $10 \%$ Chlorox for $10 \mathrm{~min}$. One hundred milliliter of spore suspension of the test fungus at $10^{4}$ 
concentration was prepared in a $250 \mathrm{ml}$ sterilized beaker. Four hundred seeds from each variety were inoculated with spore suspension and then incubated for $30 \mathrm{~min}$.

Two hundred of each healthy, spotted and inoculated seeds of two rice varieties were placed in sterilized 8 inch cotton plugged test tubes containing $5 \mathrm{ml} 2 \%$ water agar medium. Healthy seeds served as control. Observation was made for 4 weeks at 3 days intervals. Germination percentage of seeds, development of disease symptoms and mortality of seedling were recorded on healthy, diseased and inoculated seeds of two rice varieties. After 10 days of inoculation, Pestalotiopsis guepinii was re-isolated from diseased and inoculated seeds and the seedlings from those healthy seeds remained fresh.

Taxonomic enumeration of Pestalotiopsis guepinii (Desm.) Stay.

(Fig. 1)

Colonies white, cottony on PDA medium at $\mathrm{pH} 6.0$ and temperature $25 \pm 1^{\circ} \mathrm{C}$. Mycelia hyaline, septate, profusely branched. Fruiting structure black, shinning, conspicuous, conidiomata $200 \mu \mathrm{m}$.

Conidiophores short hyaline, $10-15 \times 1-2 \mu \mathrm{m}$, mostly aseptate with 1 - 2 proliferation. Conidia blackish brown, mostly three septate with 2 - 5 hyaline appendages at the apex and short hyaline appendages at the base, apical appendages $16.5-26.1 \mu \mathrm{m}$ long and basal appendages 4.2 - $7.8 \mu \mathrm{m}$ long.

Based on these morphological characteristics, the fungus was identified as Pestalotiopsis guepinii (Desm.) Stay.(12).

\section{References}

1. Miah SA, KM Shahjahan, MA Hossain and NR Sharma 1985. Survey of rice disease in Bangladesh. Tropical Pest Management 31(3): 208-213.

2. Fakir GA 1982. An annotated list of seed borne diseases in Bangladesh. Agriculture Information Service, Dhaka, Bangladesh. pp. 15.

3. Shamsi S, AKM Nowsher A Khan, AKM Shahjahan and SA Miah 2003. Fungal species associated with sheaths and grains of sheath rot affected rice varieties from Bangladesh. Bangladesh J. Bot. 32(1): 17-22.

4. Mew TW and P Gonzales 2002. A Handbook of Rice Seed Borne Fungi. IRRI. Los Banos. Philippines. pp. iv+ 83.

5. Mia MAT 2004. Production, drying and preservation of quality rice seeds at farmer level. In: Proceeding Technology Development Workshop. pp. 11-51. Organized by PETTA-IRRI and BRRI held in Bangladesh Rice Research Institute. Joydebpur, Gazipur, Dhaka.

6. CAB (Commonwealth Agricultural Bureau) 1968. Plant Pathologist Pocket Book. $1^{\text {st }}$ edn. The Commonwealth Mycological Institute, England. pp. 267.

7. Barnett HL and BB Hunter 1972. Illustrated Genera of Imperfect Fungi. Burgess Pub. Co. Minneapolis, Minnessota. pp. 241.

8. Booth C 1971. The Genus Fusarium. The Commonwealth Mycological Institute, Kew, England. pp. 221. 
9. Ellis MB 1971. Dematiaceous Hyphomycetes. The Commonwealth Mycological Institute, England. pp. 608.

10. Ellis MB 1976. More Dematiaceous Hyphomycetes. The Commonwealth Mycological Institute, England. pp. 507.

11. Ellis MB and JP Ellis 1997. Micro Fungi on Landplants. An Identification Handbook. The Commonwealth Mycological Institute, England. pp. 868.

12. Sutton BC 1980. The Coelomycetes. Fungi Imperfecti with Pycnidia Acervuli and Stromata Commonwealth Mycological Institute, England. pp. 696.

13. Reddy KS and J Subbayya. 1989. Evaluation of different method inoculation for screening rice cultivars for sheath rot resistance. ENG. Oryza. 26(4): 416-417.

14. Shamsi S, P Chowdhury and N Naher 2013. Mycoflora associated with the leaves of Senna alata (L.) Roxb. J. Bangladesh Acad. Sci. 37(2): 249-252.

15. Shutrodhar AR and S Shamsi 2013. Anthracnose and leaf spot diseases of Aloe vera L. from Bangladesh. Dhaka Univ. J. Biol. Sci. 22(2):103-108.

(Manuscript received on 25 June, 2014; revised on 25 August, 2014) 